\title{
Teachers' Readiness Indicators on ICT Integration into their Teaching
}

\author{
Rea Aisha Champa ${ }^{1}$, Dewi Rochsantiningsih ${ }^{2}$, Diah Kristiana ${ }^{2}$ \\ ${ }^{1}$ Master's Degree Program of English Education, UniversitasSebelasMaret, Surakarta,Indonesia \\ ${ }^{2}$ Universitas Sebelas Maret, Surakarta, Indonesia \\ raishachampa11@gmail.com
}

\begin{abstract}
By the rapid change in innovations of Information and Communication Technology, people are now able to get and exchange information fast. To keep up with these innovations, the integration of ICT in education is urgently demanded of time at present as ICT is being used in almost all other sectors all over the world. Therefore, it demands the teachers to be skillful in operating ICT during their teaching. Nevertheless, the integration of ICT into teaching in Indonesia hasn't fully been maximized. This paper is intended to investigate the factors of teachers' readiness to integrate ICT into their teaching. To acquire an in-depth result, this case study focuses on the interview of some teachers in a certain school in Indonesia. The data gained revealed four factors that enact the integration of ICT in class. Most of the teachers need official trainingconcerning the integration of recent ICTs in class to optimize their teaching skills using ICT.
\end{abstract}

Keywords: ICT-integration; ICT; readiness indicators

\section{Introduction}

Technological devices are developing rapidly which produces many useful sophisticated devices. This has caused an explosion of ever-changing technology that makes a world without limits. This phenomenon occurred in the 4.0 industrial revolution era. This is recognized by the occurrence of advanced technologies such as E-banking, E-learning, online shopping, and online transportation. This shift also changes the social and cultural conditions of the community.In addition, technological innovation influences scientific and technological progress in all areas of society (Bilyalova, 2017: 176; Zhang \& Aikman, 2007).There is a global trend in education policy and research to recognize the need to reform education from the traditional paradigm of teaching and learning into more innovative forms of pedagogical practices that integrate Information and Communication Technology (ICT) (Hossain et al., 2016). As Ekayati (2019) stated that in line with the development of the world of information and technology (IT) today, the method chosen must also be able to keep up withthe IT development.

Therefore, the 21th-century learning demands the integration of ICT in the educational system (Lloyd, 2005: 2) and the education system has fully realized the potential of ICT as a valuable assisting tool in teaching and learning (Drier, 2001; Vajargah\&Saadattlab, 2014).In the context of teaching and learning, technology can facilitate tasks and improve teachers' performance in creating effective teaching and learning activities. Researchers explored the use of ICT in the classroom recently. They show that integrating ICT in teaching assists teachers to develop students' proficiency (Barreh 2013; Romrell 2014; Drajati\&Rochsantiningsih 2018). It can be a medium to facilitate the learning process. As Yusrizal (2019) uttered that with the help of ICT, teachers can easily design or even directly access the media from the internet in the form of videos andimages that are relatively more practical and effective compared to conventional media.

Tinio (2013) claimed that the use of ICT is viewed as a potentially powerful enabling tool, specifically for educational change and reform. While new technologies can help teachers 
enhance their pedagogical practice, they can also assist students in their learning. The importance of ICT is used in learning so that it can indirectly foster children's interest in learning materialthrough the media used by the teacher (Yusrizal, 2019).Wong et al. (2006) pointed out that technology can play a part in supporting face-to-face teaching and learning in the classroom. Many researchers and theorists assert that the use of computers can help students to become knowledgeable, reduce the amount of direct instruction given to them, and give teachers an opportunity to help those students with particular needs (Iding, Crosby, \&Speitel, 2002; Romeo, 2006).Sudhata (2014: 25) adds several reasons for ICT to be applied in learning, including: 1) ICT can change the learning paradigm that wasoriginally teacher-centered now to be student-centered, 2) ICT learning model is an active andcollaborative learning model; and 3) ICT can increase motivation, skills, thinking structures, and in learning more actively communicate electronically.

The main key to the success of education in a country lies in the quality of teachers possessed in the country. In other words, the better the quality of teachers in a country, the better the quality of education in that country. The right step that can be done by the teacher is to change the learning pattern by incorporating elements of technology as a tool in the learning process given the rapid development of technology today (Yusrizal, 2019). In line with Cavaset. al, 2009), many believe that the success of technology integration and the effective use of technology in education mostly depend on teachers' willingness to adopt and attitudes toward technology. Students nowadays think and learn differently and perform many functions in quite distinct. Teachers of course, must know how to grasp students' attention and interests in the classroom. Therefore, teachers need to integrate ICT to add value to the teaching and learning activities. In an earlier study by Sheingold and Hadley (1990), it was also agreed that integrating technology is more than just helping people to use computers, but it is also for helping teachers to utilize it for learning.

Balanskat, Blamire, and Kefala (2006) argued that although educators appear to acknowledge the value of ICT in schools, difficulties continue to be encountered during the process of adopting the technologies. Multiple previous studies have concluded that achieving technology integration into classroom instruction is a slow and complex process that is influenced by many factors (Levin and Wadmany 2008). Potter \&Rockinson-Szapkiw (2012) stated that teachers require a shift thinking, to learn and adapt how to manage learning behavior differently as they use ICT in the classroom. In fact, most of the teachers are having obstacles in integrating technology to their learning process because they lack of proficiency. This condition is much further exacerbated by the lack of effort by teachers to use technology such as the use of laptops and the internet as supporting media in learning methods that can influence the success of the learning process itself. Even though today there are many schools that provide free internet facilities (Wi-Fi), however, these conditions have not been fully utilized by the teachers (Ekayati, 2019). Furthermore, there are still teachers who do not understand using these facilities as learning media. Some of them still use conventional media such as cartons, and objects in the surrounding environment as media in the learning process (Yusrizal, 2019).

A high percentage of teachers do not know how to integrate educational technology into their curriculum (Townsend, 2017: 12). Mishra \& Koehler (2008: 10) stated that teaching with technology is a "wicked problem" for teachers that it has "incomplete, contradictory and changing requirements". However, education practitioners slowly but sure has to willy-nilly become digitalized in any section. It is urged by the changes of era, the demand of the digital students, and also a mandate of the Indonesian Government. With the reality of the integration 
of ICT in teaching and learning process, this study aims to investigate the indicators of teachers' readiness to integrate ICT into their teaching,

\section{Review of Literature}

\subsection{ICT and its Integration in Education}

Warsita (2008: 135) Information and Communication Technology is of hard ware and software and the method to gain, send and processing the data meaningfully. It is a complex technology that needs some components to make it work. Floris (2014, p. 140) pinpoints that ICT includes the Internet, wireless networks, cell phones, and other communication mediums. Likewise, Toomey (2001, as cited in Margaret, 2005, p. 3) posits that ICT could include hardware (e.g. computers and other devices); software applications; and connectivity (e.g. access to the Internet, local networking infrastructure, video conferencing). Moreover, Perron et al. (2010, p. 67) suggest that ICT can include email, SMS text messaging, video chat (e.g. Skype), and online social media (e.g. Facebook) as well as computing devices (e.g. laptop computers and smartphones) that carry out a wide range of communication and information functions.

The occurrence of ICT in Education was started in the early of 80's. The first issue was computer in education. It became popular when relatively computers began available and easy to get in the market. In 1922 electronic mail emerged to be used for public which was initiated the term of ICT. It is used as a supportive tool in teaching in the form of technology machines such as Internet, Intranet, CD ROM, video tape, DVD, TV, Hand phone, etc.ICT in classroom does not replace the traditional face-to-face instruction, yet it is used as a supportive tool in teaching and learning. Therefore, teacher's creativity to manage and to create interesting learning activities for students is the key for the effectiveness of ICT use in teaching and learning process.

ICT will provide benefits for teachers and students in learning in the school as it is developed and used well. Research in West and Central Africa shows that, ICT for teaching and learning in university environments can contribute to developing a more student-centered approach to pedagogy (Hossain at al., 2016). Generally, the benefits gained by integrating ICT in learning in the classroom are: it makes the process of teaching and learning to be more interesting and more interactive, students will get more involved in the process of teaching and learning.

\subsection{Teachers' Readiness Factors in Integrating ICT}

According to Saekow and Samson (2011), to successfully integrate ICT, learning institutions should first assess their ict-readiness to integrate the technology). Teachers' readiness defined as teacher perception of their capabilities and skills required to integrate technology into their classroom instruction (Inan at al., 2010). Borotis and Poulymenakou (2008) defined tech-learning readiness as "the mental or physical preparedness of an organization for some e-learning experience or action". Teacher's readiness to integrate ICT is concluded as teachers' perception and physical preparedness of their capabilities and skills to integrate technology into their classroom instruction.

Teachers' perceptions, attitudes and believes towards technologies influenced the effective use of technologies in teaching and learning (Paraskeva, at al., 2008). Talcin, at al. (2011) also stated that teachers' pedagogical beliefs are an important variable that influences teachers' use of technology in the classroom. Webster and Hackley (1997) claimed three 
characteristics of instructors that influence student performance: attitude towards technology; teaching style; and control of the technology. There seem to be four major issues identified by research for introducing technology in higher education practices in Bangladesh. These are: beliefs: personal ideas about the contribution that technology can make to the processes of teaching and learning and classroom management; experience: own training and ICT skills, abilities to control ICT use in the classroom and cope with technical failure; resources: available technologies in schools and ownership of own computer at home; community: membership to a network of colleagues who can provide support, encourage use and constitute a learning community (Hossain at al., 2016). Mercado (2008) claimed the factors affecting the integration of ICT in teaching are technology access, technical skills and, attitude and institutional readiness which refers to the availability of the technologies.

From those experts and researches they had conducted, researcher has summarized the parameters or indicators which represent the teachers' readiness in integrating ICT into their teaching, they are: belief since it's believed that belief may affect the ones' performance;skillwhich covers their knowledge and capability; experience which create a creature; and also tool; that covers the availability of tool (technology) and also teaching materials.

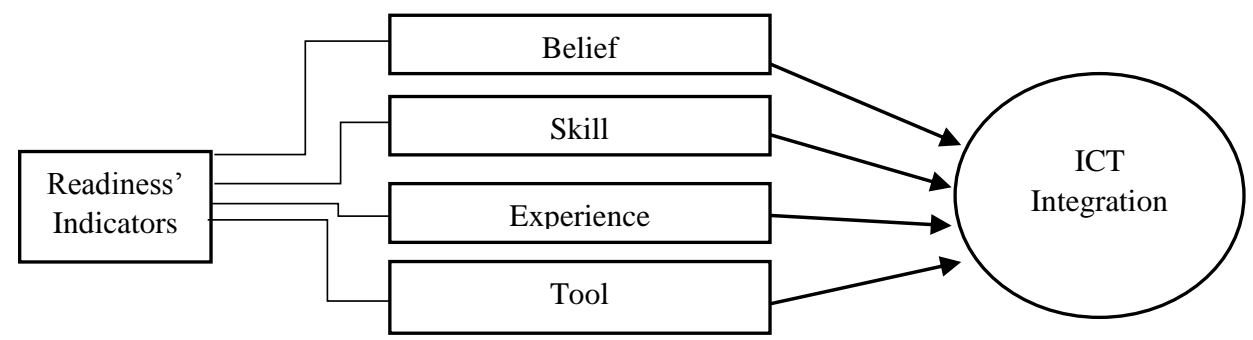

Figure 1. Teachers' Readiness Indicators in Integrating ICT

\section{Research Method}

This study is intended to discover the readiness' factors of teachers which effecting the integration of ICT in teaching and also reveal the teachers' need to enhance their digitalized teaching by employing qualitative approach. Data were collected through questionnaires and in-depth interview focusing on the factors of the ICT integration and also their needs in teaching and learning process. The informants are 48 English teachers in Indonesia; three of them were directly interviewed as a representative. The interviewees are three English teachers in Surakarta namely $\mathrm{Dh}, \mathrm{Wk}$, and Ds. The process of collecting and analyzing the data continuously bundled together to complete information comprehensively, as Miles and Huberman (1994) noted that in Qualitative Design, Data Collection, Data Display, Data Reduction, and Data Verification or Conclusion connect each other.

\section{Result and Discussion}

\subsection{Teachers' Readiness Factors to Integrate ICT into Teaching}

From four factors that affecting the teachers' readiness in integrating ICT. Researchers had made and distributed a questionnaire regarding those issues. There are 26 questions on questionnaire that have been answered by the informants. Every six questions represent each indicators of teachers' readiness in integrating ICT into teaching. The result of each indicator is presented on Table 1: 
Table 1.The Result of the ICT Integration's Readiness

\begin{tabular}{|c|l|c|}
\hline No. & \multicolumn{1}{|c|}{ Indicators } & Percentage \\
\hline 1. & Belief & $82 \%$ \\
\hline 2. & Tool & $67.7 \%$ \\
\hline 3. & Experience & $65.3 \%$ \\
\hline 4. & Skill & $60.2 \%$ \\
\hline \multicolumn{2}{|c|}{ Average Readiness } & $\mathbf{6 8 . 8 \%}$ \\
\hline
\end{tabular}

\subsection{ICT-Integration Factor: Belief}

Belief refers to teachers' assumption about the use of ICT in teaching. This factor is the highest out of four factors that the teachers don't have problem of. Almost most of them assume that the integration of ICT. The highest percentage is on the statement "Teachers need to have the provision of ICT knowledge to teach" on $94 \%$ means that most of them realize that ICT is now an important aspect in teaching that should be learned by the recent teachers.

From the result of the interview all the three teachers are in line that ICT is useful and can maximized the teaching and learning process in the class. As Teacher Ds said, "by using technologies, teaching and learning process becomes easier, more effective and also practical." From this result it can be concluded that belief is not a problem that teachers have regarding the not-maximized used of ICT in class. The teachers have a great foundation to enhancing their ICT skill because they have got a positive belief towards ICT Integration. A school could have ICT hardware and software, but whether used efficiently will depend on the teachers. It will depend on the teachers' beliefs andexperiences, levels of knowledge, attitude towards ICT, educational applications, the expectedoutcomes and the teaching and learning approach (Thomas and Stratton, 2006).

\subsection{ICT-Integration Factor: Tool}

The second factor is tool deals with the equipment of ICT both software and hardware. Even though it is on the second place with $67.7 \%$, it still remains low. The lowest percentage on this factor is on the statement "Designing a material in the form of soft file is time consuming" with $60 \%$. From the interview conducted teacher Wk added "terachers have many duties to do, especially for those who have already have a certain position in that school. Becoming a homeroom teacher, assisting the students who are going to join a competition, having a responsibility to handling an event for schools, creating lesson plans, scoring the students' ability, etc. There's no time, sometimes, to turn the materials into digital - PPT or video or even in the form of Microsoft words."

Teacher Dh has her own view about the lack of applicable application for teaching, "there are many applications with learning theme, but those which are appropriate and suitable for the material are very few. Even if there is, it is certainly not flexible to operate and surely will take time for students and teachers to adapt and understand how to use the application". Lack of appropriate software discourage the integration of ICT in learning. In Goktas and Yildrim's research (2009), they claimed lack of software is one of the barriers' lists in integrating ICT in teaching and learning process. Insufficient proper and practical software in terms of application can't enrich the teachers' learning using technology. They will tend to use the basic software of application. One of the main barriers of integrating ICT into teaching and learning process is lack of appropriate software (Bullock, 2004; Muantaz 2000). 


\subsection{ICT-Integration Factor: Experience}

Experience seems to be the wicked issues for the teachers. It is unchangeable state of an individual. It seems to be the factor that makes the integration of ICT in a classroom isn't working as how it should be. It's the third place with the $65.3 \%$ which also considered low. "I have attended training on the use of ICT in learning less than 3 times" with the $52 \%$ that means most of the teachers have insufficient training to train them operating technologies into their teaching. Teacher Dh said, "there's no official training from government giving us proper view of using ICT in teaching and learning process. It makes me confuse whether I already integrate ICT well or I still need improvement." In line with teacher Dh, teacher Wk and Ds also claimed that no official training from government to assist them integrating ICT in teaching and learning process. Teacher Ds added, "Frankly the use of technology in the classroom has no training from the government, in fact we need to know how to use technology properly during the lesson in class."

Studies also have well explored that lack of training is a significant problem for the teacher to use pedagogical ICT in teaching (Anderson et al., 1984: 13). It may a signal that teachers' incompetence to use various modern ICTs in teaching is caused by the insufficient training that the teachers receive. This finding is also found in Pelgrum's (2001) study that there were not enough training opportunities for teachers in the use of ICTs in a classroom environment. Similarly, Beggs (2000) found that one of the top three barriers to teachers' use of ICT in teaching students was the lack of training. Recent research in Turkey found that the main problem with the implementation of new ICT in science was the insufficient amount of in-service training programs for science teachers (Özden, 2007), and Toprakci (2006) concluded that limited teacher training in the use of ICT in Turkish schools is an obstacle. As it is assumed that as the teacher has lack of competence to integrate ICT, it means that the country did not yet succeed in realizing sufficient facilities to train teachers with technologies (Pelgrum, 2001). Meanwhile, governments and the stakes holders are supposed to monitor and guide the implementation of ICT in teaching. It is since having policies without a proper implementation and monitoring makes no sense (Jude, 2014: 110).

\subsection{ICT-Integration Factor: Skill}

The least percentage of the ICT integration's readiness is skill. It refers to one's ability and capability to operate, manage, and optimize technologies, both software such as applications and also hardware such as laptop, projector, speaker, etc., into their teaching. From the questionnaire, skill gets $60.2 \%$ which is the least percentage from the other indicators. This indicator becomes the most influencing factor that influence the teachers' ICT integration in teaching and learning process, and even maybe the one that make the integration of ICT in class isn't optimized.

The three teachers whom I interviewed have already mastered operating the basic software to support the learning process, such as Microsoft word and power point. However when it comes into a complex use of technology to support the learning, the lack of competence to operate an educational application occurred to become one of the challenges faced by the teachers. Teacher Dh said, "the complexity of the application operation makes me feel technologically blind. This makes me discourage to use certain applications to support learning." Teacher Ds is experiencing the same as teacher Re, "the lack of training on how to use applications that support classroom learning made me feel that I was still lacking in using technology during students' learning. I only integrate ICT monotonically." 
These situation is similar with $\mathrm{Hu}$ and Garimella's and also several other researches. A high percentage of teachers do not know how to integrate educational technology into their curriculum (Hu \&Garimella, 2014). Newhouse (2002) found that many teachers lack the knowledge and skills to use computers. They were also not enthusiastic about the changes and integration of supplementary learning associated with bringing computers into their teaching practices. Teachers' lack of knowledge and skills is a serious obstacle to using ICT in primary and secondary schools. (Pelgrum 2001).Balanskat et al. (2006) have shown that in Denmark many teachers still chose not to use ICT and media in teaching situations because of their lack of ICT skills rather than for pedagogical or didactics.

\section{Conclusion}

The teachers are beginner users regarding their competence level to use ICT in teaching. They use more basic function in a limited number of computer applications in teaching than ICTs categorized in average and advanced. From these facts and situations it can be considered that the teachers haven't fully ready to integrate ICT into their teaching. There are four indicators which influencing the readiness of teachers' ICT integration in the class which was got by the experts. They are belief, tool, experience and skill. From the research that I conducted, it shows that the readiness of Indonesian teachers' to integrate ICT is around 68.8 $\%$. It can be classified as moderately lowwhich means that the integration of ICT in Indonesia hasn't be maximized yet by the teachers.

\section{References}

Anderson, C. A., Smith, R. L., Anderson, C. A., Smith, R. L., Computing, I., Anderson, C. A., \& Smith, R. L. (2016). Instructional Computing Patterns in Texas Schools : Implications for Teacher Training Instructional Computing Patterns in Texas Schools : Implications for Teacher Training, 1037(June). https://doi.org/10.1080/00011037.1984.11008381

Balanskat, A., Blamire, R., \&Kefala, S. (2006). A review of studies of ICT impact on schools in Europe: European Schoolnet.

Barreh, Kadar A., \& Abas Z. W. (2013). A Framework for Mobile Learning for Enhancing Learning in Higher Education.Malaysian Online Journal of Educational Technology, 3(3). Retrieved from www.mojet.net

Bilyalova, A. (2017). ICT in Teaching a Foreign Language in High School.Procedia - Social and Behavioral Sciences, 237(June 2016), pp.175-181.

Borotis, S., Zaharias, P., \&Poulymenakou, A. (2008). Critical success factors for e-learning adoption. In Handbook of Research on Instructional Systems and Technology (pp. 498513).IGI Global.

Bullock, D. (2004). Moving from theory to practice: An examination of the factors that preservice teachers encounter as they attempt to gain experience teaching with technology during field placement experiences, Journal of Technology and Teacher Education, 211-237.

Cavas, B., Cavas, P., Karaoglan, B., \& Kalsa, T. (2009). A study on science teachers' attitudes toward information and communication technologies in education. The Turkish Online Journal of Educational Technology, 8(2), 34-67.

Drier, H.S. (2001). Teaching and learning mathematics with interactive spreadsheets. School Science and mathematics, 101 (4), 170-179 
Drajati, Nur Arifah\& Tan, LyndeHaryati\&Haryati, Sri, A., \&Zainnuri, \&Rochsantiningsih, Dewi\&Zainnuri, H. (2018). Investigating English Language Teachers in Developing TPACK and Multimodal Literacy. Indonesian Journal of Applied Linguistics, 7(January), 575-582. https://doi.org/10.17509/ijal.v7i3.9806

Ekayati, R. (2019). Study of Blended-Learning Method Assisted By Edmodo in Teaching English at State Vocational School in Deli Serdang. Budapest International Research and Critics in Linguistics and Education (BirLE) Journal, 2(3), 18-26.

Fauzi, A. (2018). Ict Acceptance Of Indonesian Teachers In Tefl: A Case Study Of Senior High School Efl Teachers (Doctoral dissertation, Universitas Sebelas Maret).

Floris, F. D. (2013). Social media in a content course for the digital natives.TEFLIN Journal, 24(1), 48-61.

Goktas, Y., Yildirim, Z., \&Yildirim, S. (2009). Investigation of K-12 teachers' ICT competencies and the contributing factors in acquiring these competencies. The New Educational Review, 17(1), 276-294.

Hossain, M. A., Salam, M. A., Shilpi, F., \& Officer, A. D. (2016).Readiness and challenges of using Information and Communications Technology (ICT) in higher education of Bangladesh. The Online Journal of New Horizons in Education, 6(1), 123-132.

Hu, H., \&Garimella, U. (2014).iPads for STEM Teachers: A case study on perceived usefulness, perceived proficiency, intention to adopt, and integration in K-12 instruction. Journal of Educational Technology Development and Exchange, 7(1), 49-66.

Iding, M., Crosby, M. E., \&Speitel, T. (2002). Teachers and technology: Beliefs and practices. International Journal of Instructional Media, 29(2), 153-171.Zhang, P., \& Aikman, S. (2007). Attitudes in ICT Acceptance and use. In J. Jacko (Ed.), Human-Computer Interaction, Part I (pp. 1021-1030). Syracuse, NY: Springer-Verlag Berlin Heidelberg.

Inan, F. A., \&Lowther, D. L. (2010). Laptops in the K-12 classrooms: Exploring factors impacting instructional use. Computers \& Education, 55(3), 937-944.

Jude, L. T., Kajura, M. A., \& Birevu, M. P. (2014). Adoption of the SAMR Model to Asses ICT Pedagogical Adoption: A Case of Makerere University, 4(2). https://doi.org/10.7763/IJEEEE.2014.V4.312

Lloyd, M. (2005).Towards a definition of the integration of ICT in the classroom. Proceedings AARE '05 Education Research - Creative Dissent: Constructive Soutions, 1-18. https://doi.org/10.1063/1.2130520

Margaret, L. (2005). Towards a definition of the integration of ICT in the classroom. In AARE 2005, AARE (Eds.), Proceeding of AARE '05 Education Research - Creative Dissent: Constructive Solutions. Paramatta, New South Wales.

Mercado, C. (2008). Readiness assessment tool for an e-learning environment implementation. In Fifth International Conference on E-Learning for Knowledge based Society (pp. 183-187).

Mikre, F. (2011). The roles of information communication technologies in education: Review article with emphasis to the computer and internet. Ethiopian Journal of Education and Sciences, 6(2), 109-126.

Miles, M. A. (1994). Miles and Huberman (1994)-Chapter 4.pdf. Qualitative Data Analysis: An Expanded Sourcebook, 50-72.

Mishra, P., \& Koehler, M. J. (2008). Introducing technological pedagogical content knowledge.In annual meeting of the American Educational Research Association (pp. 1-16).

Mumtaz, S. (2000). Factors affecting teachers' use of information and communications technology: A review of the literature. Journal of information Tachnology of Teacher Education, 9(3), 319-341. 
Newhouse, P. (2002). Literature review: The impact of ICT on learning and teaching, Perth, Western Australia: Department of Education.

Özden, M. (2007).Problems with science and technology education in Turkey. Eurasia Journal of Mathematics, Science \& Technology Education, 3(2), 157-161.

Paraskeva, F.; Bouta, H. and Papagianna, A. (2008).Individual characteristics and computer self-efficacy in secondary education teachers to integrate technology in educational practice. In Computer and Education, 50(3), (pp. 1084-1091).

Pelgrum, W. J. (2001). Obstacles to the integration of ICT in education: results from a worldwide educational assessment. Computers \& Education, 37, 163-178

Perron, B. E., Taylor, H. O., Glass, J. E., \&Margerum-Leys, J. (2010).Information and communication technology in social work. Advances in Social Work, 11(1), 67-81.

Romeo, G. I. (2006). Engage, empower, enable: Developing a shared vision for technology in education In M. S. Khine (Ed.), Engaged Learning and Emerging Technologies. The Netherlands: Springer Science.

Romrell, D., Kidder, L. C., \& Wood, E. (2014).The SAMR model as a framework for evaluating mLearning. Journal of Asynchronous Learning Network, 18(2), 1-15.

Saekow, A., \& Samson, D. (2011).E-learning Readiness of Thailand's UniversitiesComparing to the USA's Cases.International Journal of e-Education, e-Business, e-Management and e-Learning, 1(2), 126.

Sudatha. I. G. Wawan. 2014. Peningkatan Kompetensi Guru Melalui Pelatihan Merancang Pembelajaran Terintegrasi Teknologi Informasi Dan Komunikasi (TIK) Pada Guru-Guru SMP Di Kecamatan Buleleng. Seminar Nasional Teknologi Pembelajaran, 22-29.

Thomas, A., \& Stratton, G. (2006). What we are really doing with ICT in physical education: a national audit of equipment, use, teacher attitudes, support, and training. British Journal of Educational Technology, 37(4), 617-632.

Tinio, Victoria L. (2003). ICT in Education. Manila: e-ASE Force. Accessed on January 2019, Retrieved from https://en.wikibooks.org/wiki/ICT_in_Education/Notes\#84

Toprakci, E. (2006). Obstacles at integration of schools into information and communication technologies by taking into consideration the opinions of the teachers and principals of primary and secondary schools in Turkey. Journal of Instructional Science and Technology (e-JIST), 9(1), 1-16

Townsend, M. B. (2017). IpadsIn K-12 Schools : A Grounded Theory Study Of Value. University of Phoenix.

Vajargah, K. F., \& Saadattlab, A. (2014). A feasibility study of using ict in Iranian secondary schools: The case of Tehran province. Tojet, 13(3)

Webster, J., \&Hackley, P. (1997).Teaching effectiveness in technology-mediated distance learning. Academy of management journal, 40(6), 1282-1309.

Warsita, B. (2008). Teknologi pembelajaran landasan dan aplikasinya. Jakarta: Rineka Cipta, 135.

Wong, A. F. L., Quek, C.-L., Divaharan, S., Liu, W.-C., Peer, J., \& Williams, M. D. (2006).Singapore students' and teachers' perceptions of computer-supported Project Work classroom learning environments. Journal of Research on Technology in Education, 38(4), 449-479.

Yusrizal, Y., Hajar, I., \& Tanjung, S. (2019). Analysis of Elementary School Teachers' Ability in Using ICT Media and Its Impact on the Interest to Learn of Students in Banda Aceh. Budapest International Research and Critics in Linguistics and Education (BirLE) Journal, 2(3), 45-57. 